$\mathrm{Oz}$

$1-1-2018$

\title{
Spatial Inquiry
}

Annie Han

Lead Pencil Studio

Daniel Mihalyo

Lead Pencil Studio

Follow this and additional works at: https://newprairiepress.org/oz

Part of the Architecture Commons

\section{(c) (1) $\Theta$}

This work is licensed under a Creative Commons Attribution-Noncommercial-No Derivative Works 4.0 License.

\section{Recommended Citation}

Han, Annie and Mihalyo, Daniel (2018) "Spatial Inquiry," Oz: Vol. 40. https://doi.org/10.4148/

2378-5853.1591

This Article is brought to you for free and open access by New Prairie Press. It has been accepted for inclusion in Oz by an authorized administrator of New Prairie Press. For more information, please contact cads@k-state.edu. 


\title{
Spatial Inquiry
}

\author{
Annie Han and Daniel Mihalyo \\ Lead Pencil Studio
}

Observe the street, from time to time, with some concern for system perhaps. Apply yourself. Take your time.

Nothing strikes you. You don't know how to see.

You must set about it more slowly, almost stupidly.

Force yourself to write down what is of no interest,

what is most obvious, most common, most colorless -Georges Perec
Species of Spaces

We have always found it difficult to practice architecture in the way it was handed down to us by the professional guild and still experience and create architecture the way we found it to be meaningful. It seems to us that space and structure created for no further reason than to be perceived and experienced is a wonderful pursuit which has little commercial use in this cultural economy. As such, our practice is an architecture in reverse. Our interest in the discipline of architecture is an exploration of the aesthetic and social qualities of constructed space stripped of utilitarian function. We are far less interested in the container than we are about that which is contained. We would rather recover the unlimited potential of the incomplete intention than arrive at concrete conclusions. We find ourselves drawn to the physical and mental influence that space exerts on the human psyche and feel joy exploring the perceptual limits of

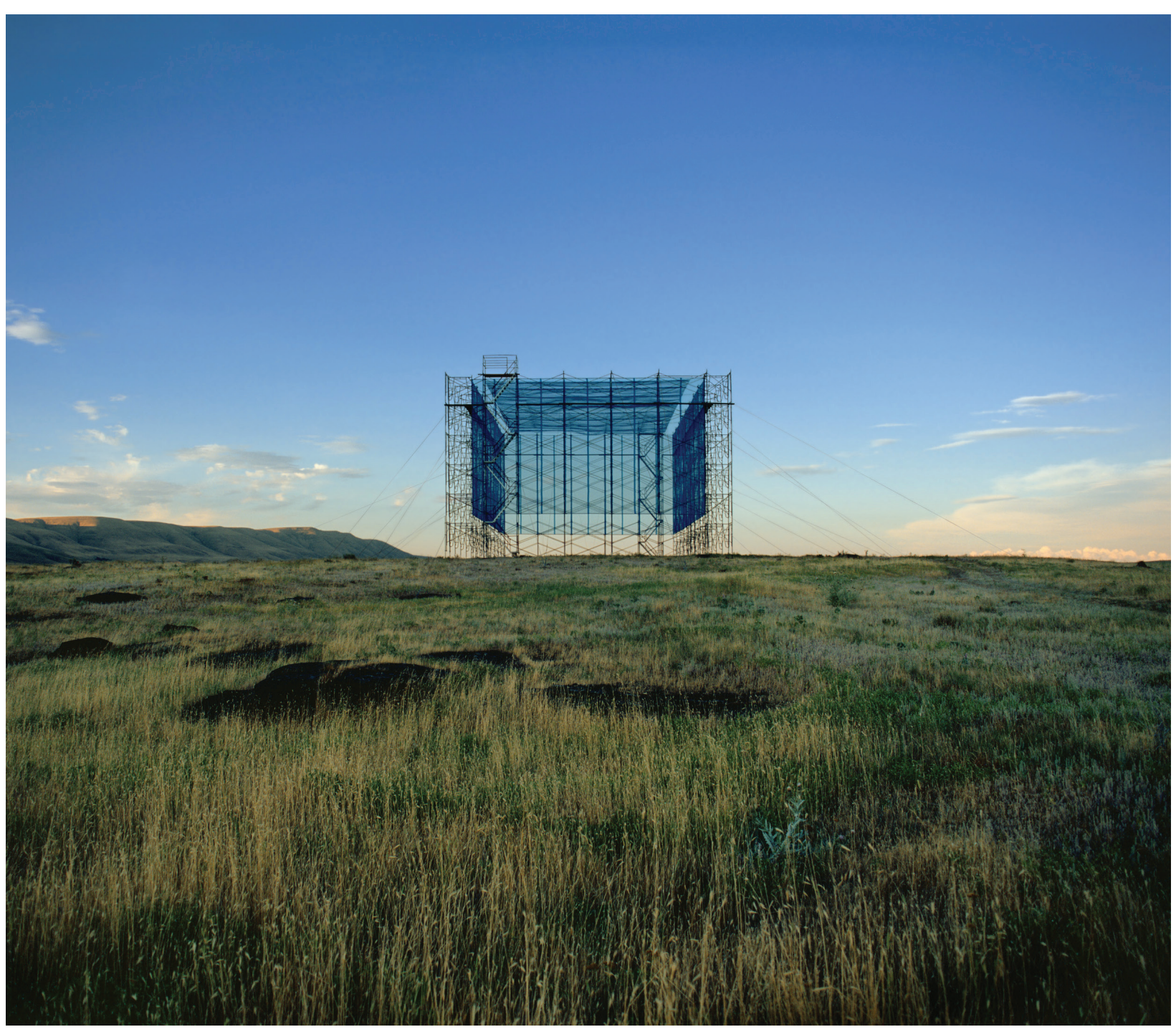

We evolved into this way of thinking about architecture in the late 1990s as we emerged from a traditional education and internship trajectory. It began even earlier, as our interests in school kept leading us to toward the workings of artists, artistic pro- cesses, art history, and studio courses in the visual arts. Shortly after graduation and not long into professional internships in Seattle, we began to recognize the pre-determined outcomes inherent in the practice of architecture. Somehow, the unlimited creative possibility of architecture and construction seemed exceptionally narrowed in residential and commercial practice. The more buildings we churned out the more we felt a suffocating dread. We reacted decisively by dropping out and reassessing. 


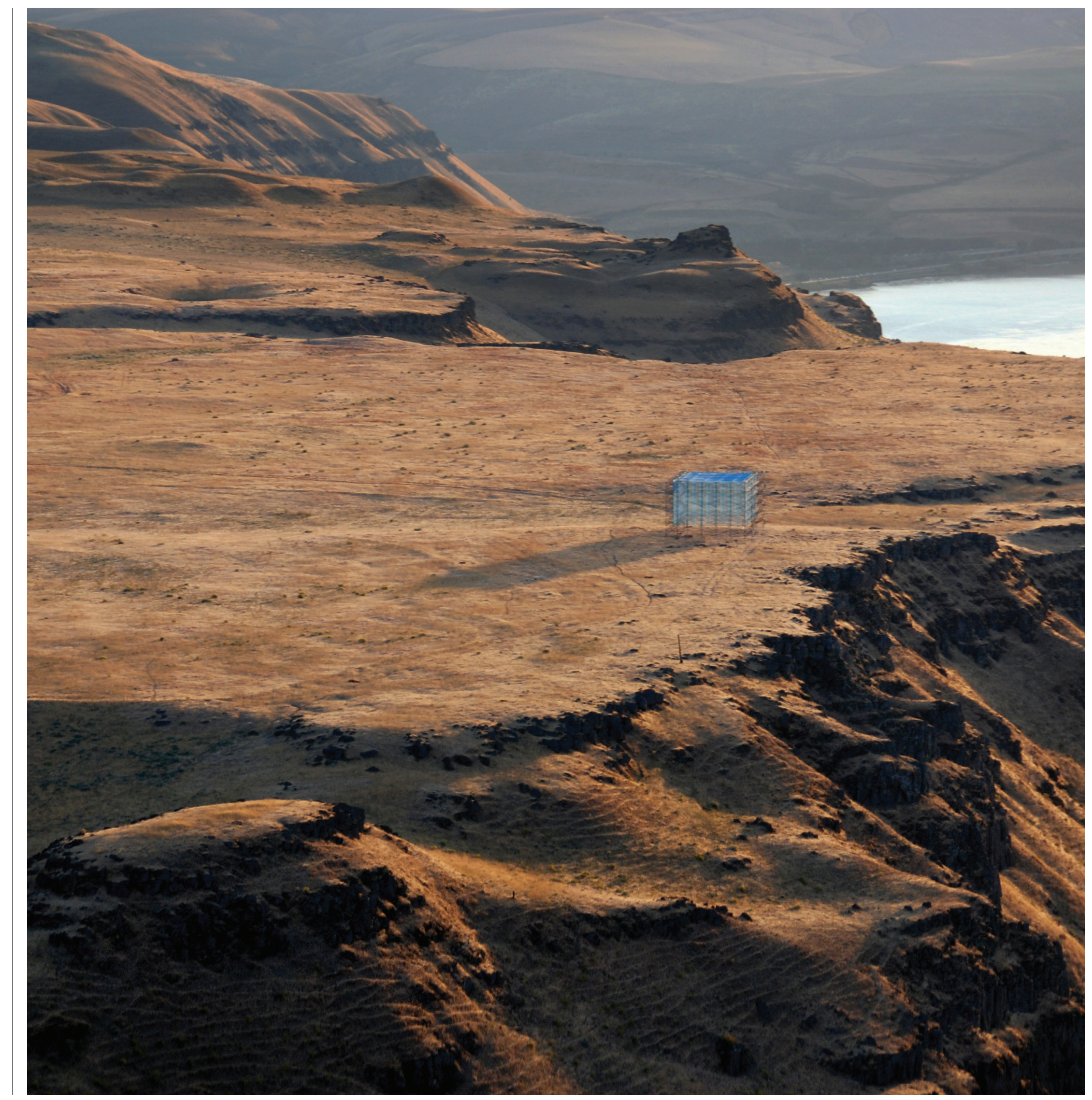




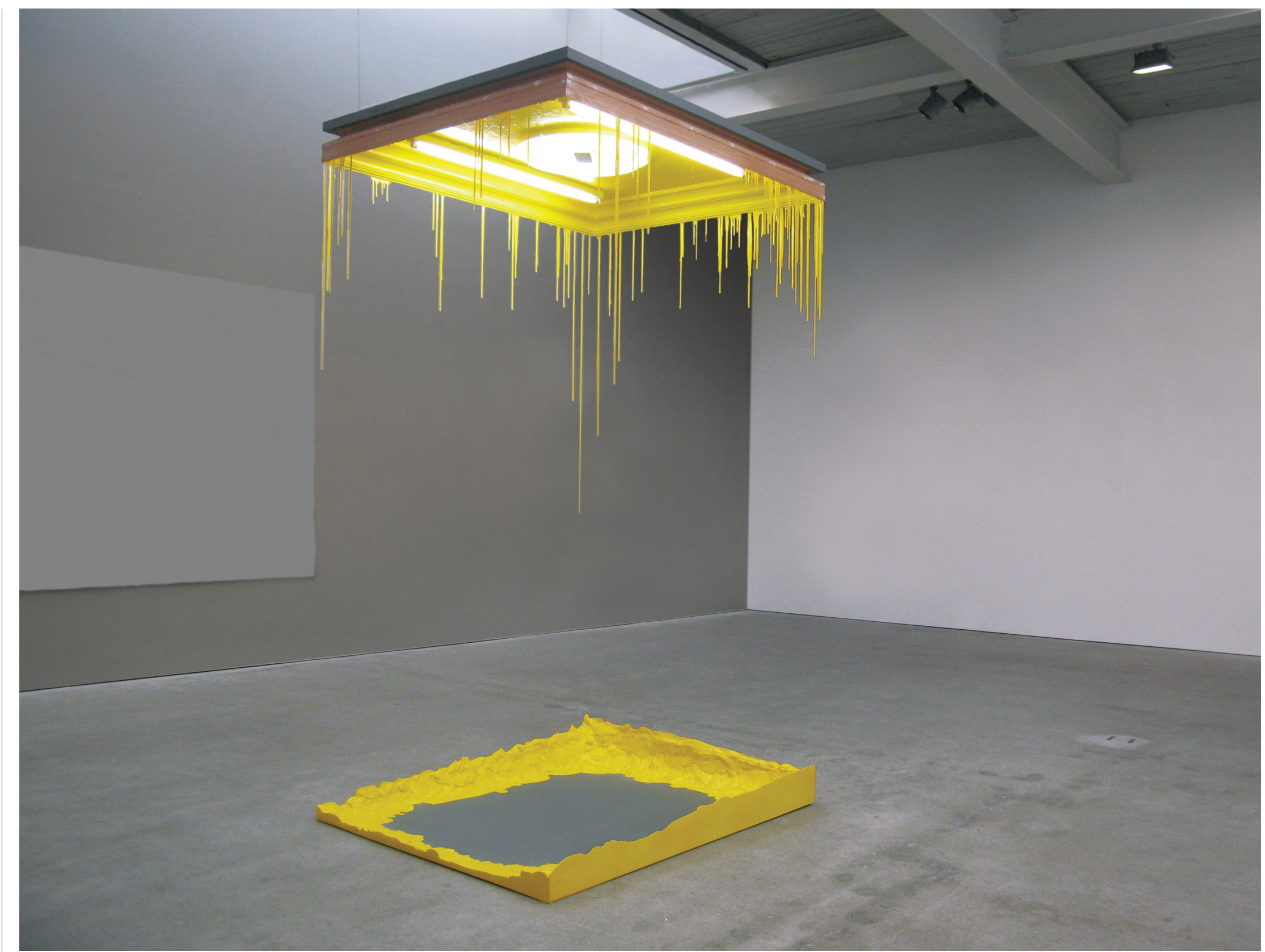

This was 1997. We traveled around North America by car, finished a book documenting a sawmill typology, and then traveled to Europe and came back to Seattle ready to make some changes. We started by cutting our overhead down to near zero to begin investing time starting our own exploration. This time of reflection led us into the inherent conflict between calling of art where we began again with our absolute love for negative space and building.

It has been our observation that the problem with the dual disciplinary pursuit of art and architecture stems from the stubborn reality of the extreme difficulty of becoming a good architect. It is often quoted that an architect takes half a lifetime to develop-an adage that we would not disavow. During the process of becoming an architect with even modest talent, the qualities needed to become a good artist disappear in inverse proportion to the exact skills needed of the other. We speak of the artistic virtues of not giving a shit, irrational thinking, not playing by the rules, alluring youth, knowledge of contemporary art theory from
1950 onward, and resisting formality. This is a possible explanation of why there are few, if any, successful crossovers in mid-career of one discipline to another. Hearing this adage in our youth, we made the unlikely choice of making no decision at all. This semi-unintentional non-binary position has lead us into a grey area where we continually function at the periphery of both disciplines. Highly 


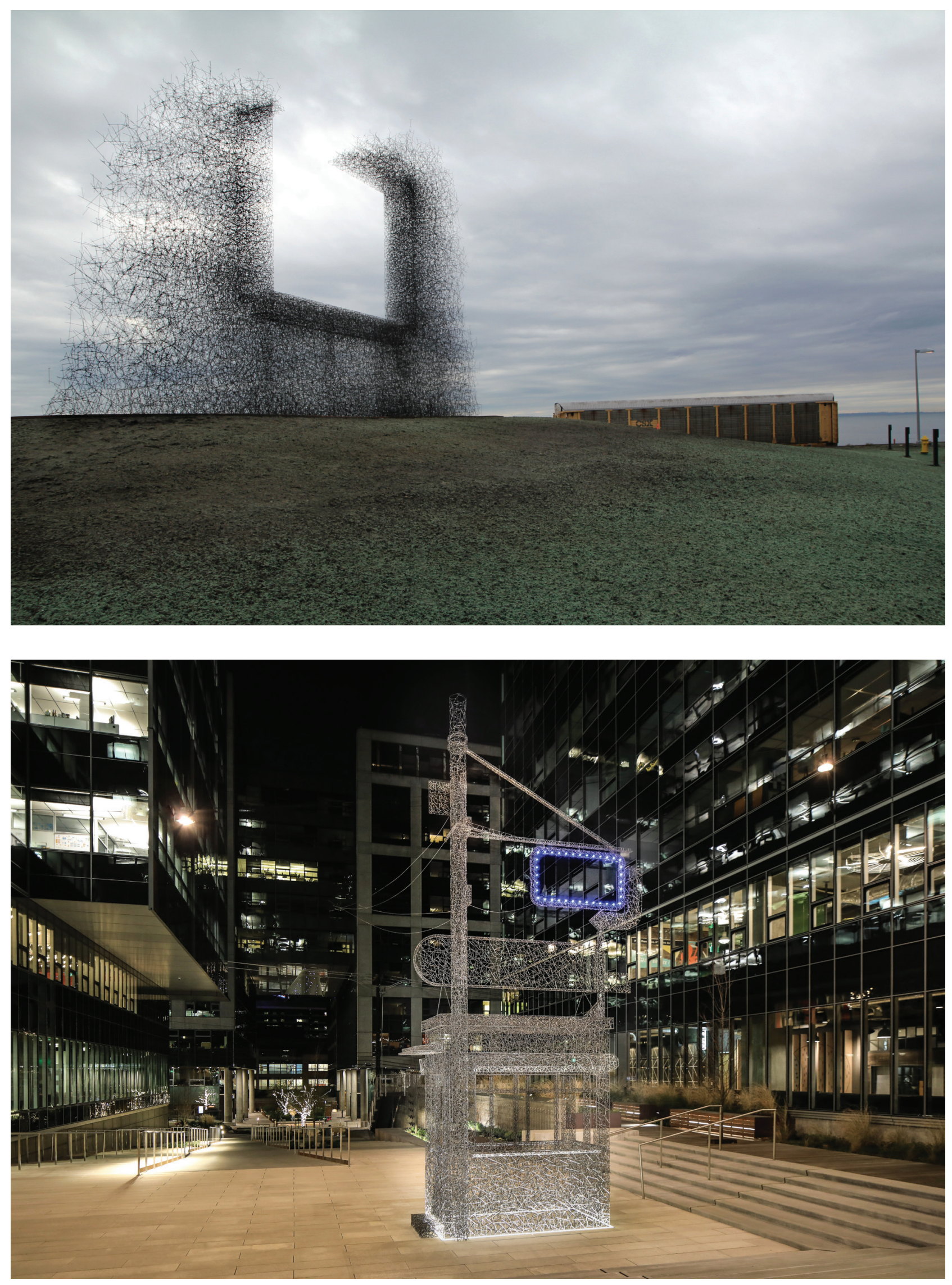




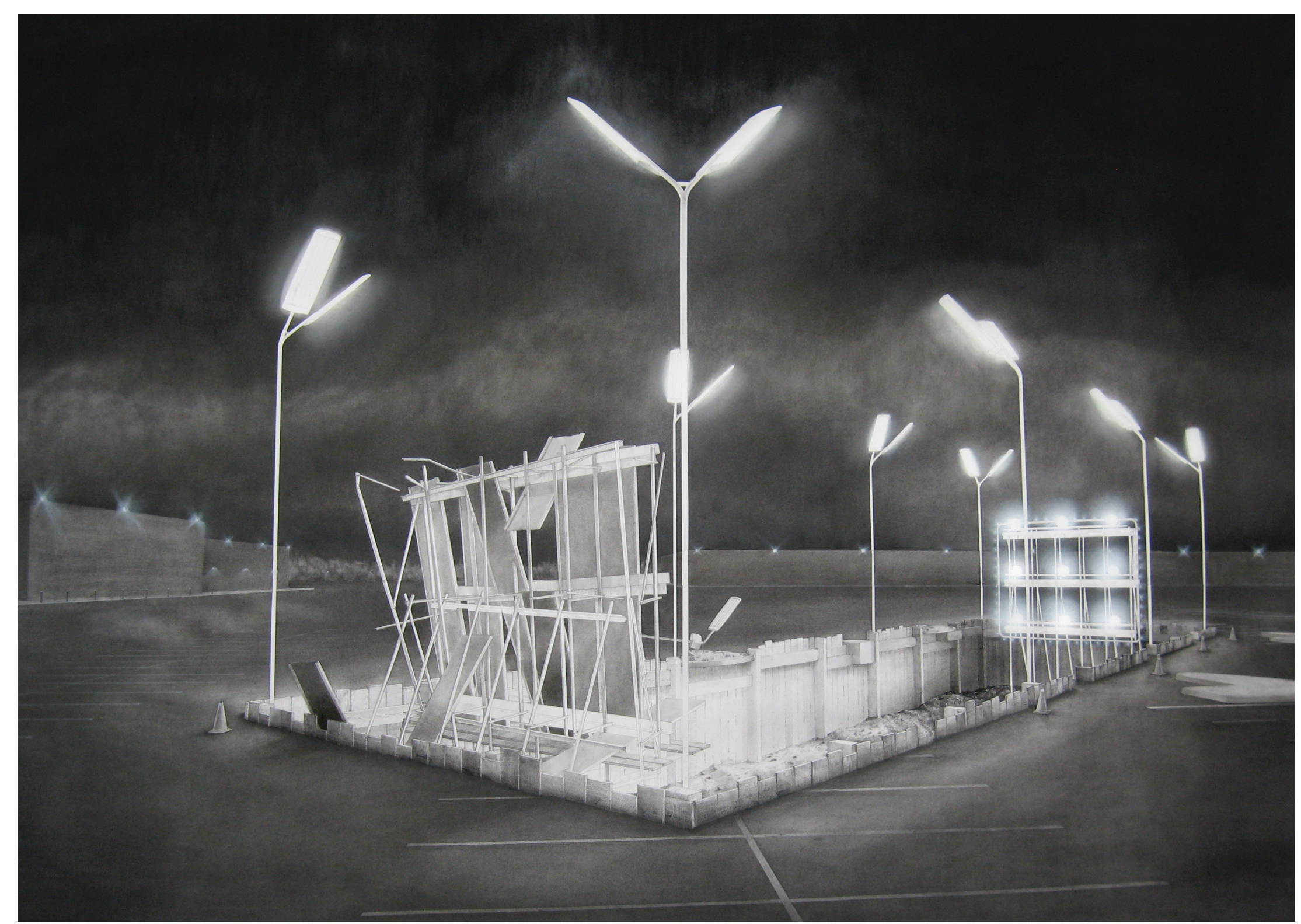



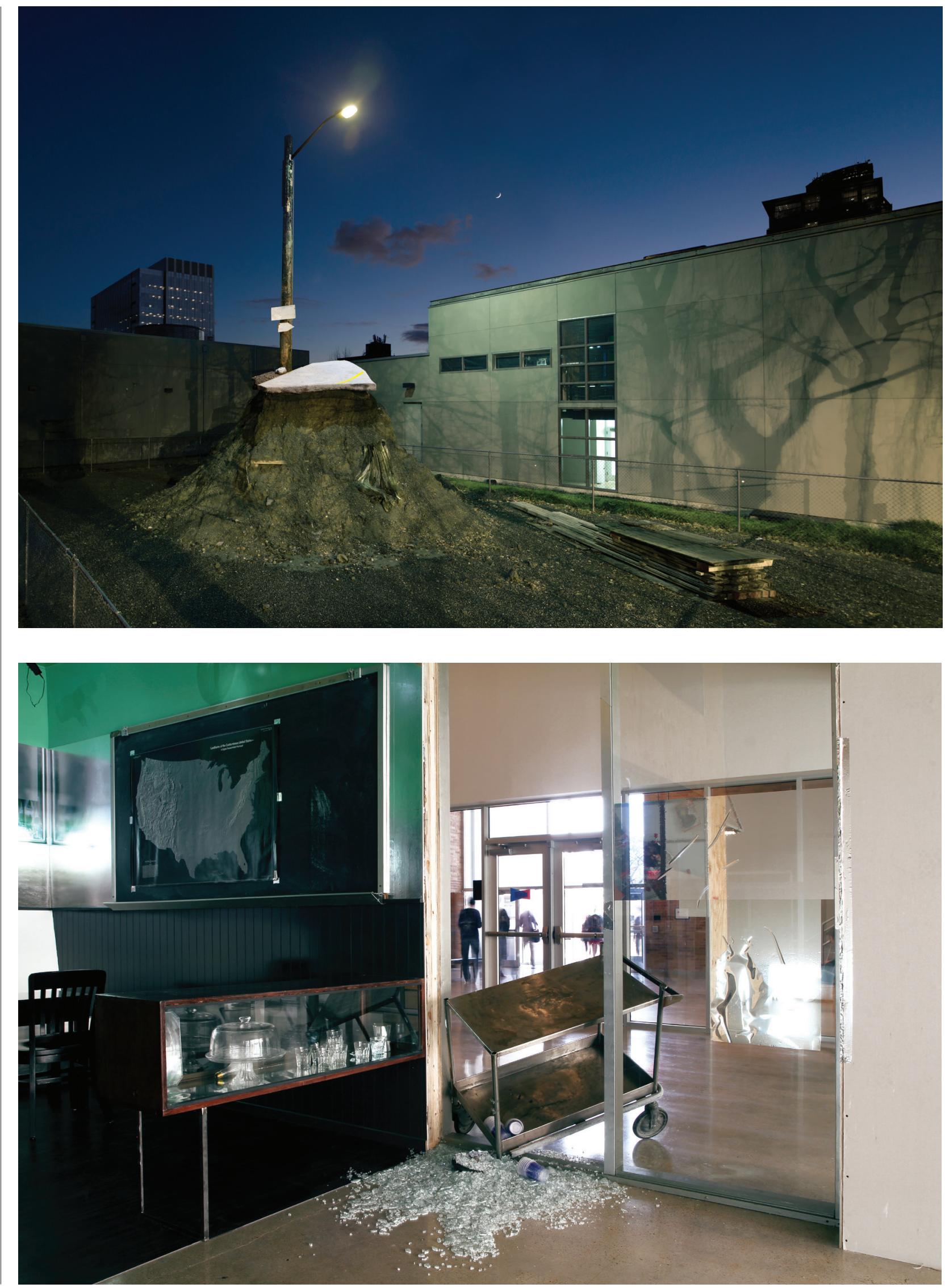

suspicious of pursuing professional standing and forever on the outside of currents in contemporary art, we plod onward with explorations that we find personally fulfilling and authentic to our love for architecture. If a description of these motivations is not clear, then let us list a few ideas whose exploration are utterly out of place in the field of architecture as we know. We do this as away of demonstrating that architecture as we know it is in an incredibly restricted territory:

Construct a space without form, program or a clearly defined boundary for no one

A new national assembly building intended as a perpetual state of partial completion

Singular architectural conditions minutely exhausted-for example a building that is only a window

Destruction as a construction process as well as an end

Express any emotional state in the practice of architecture other than social utopian progressivism

Acts of architecture as a critical position to art and in critical opposition to architecture

Emptiness, loss, and disquiet as nodes of wonder

The ugly, weak, poorly considered, and tasteless as the next best style in architecture

Architecture as an act of war

Consider the coming ice age 